
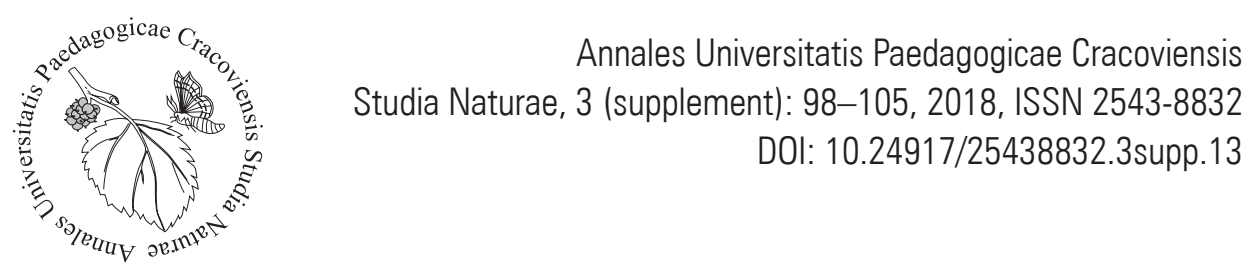

DOI: $10.24917 / 25438832.3$ supp.13

Thiep Vo Van ${ }^{1,2^{*}}$, Łukasz J. Binkowski ${ }^{1}$, Robert Stawarz ${ }^{1}$

${ }^{1}$ Institute of Biology, Pedagogical University of Cracow, Podchorazych 2, 30-084 Kraków, Poland ${ }^{2}$ Faculty of Agriculture, Forestry and Fisheries, Quang Binh University, 312 Ly Thuong Kiet Str,

Dong Hoi, Quang Binh, Vietnam, *thiep.vo-van@up.krakow.pl

\title{
The concentration of mercury in organs of Whipfin silver biddy (Gerres filamentosus Cuv.) and Flathead grey mullet (Mugil cephalus L.) in coastal central Vietnam
}

\section{Introduction}

Vietnam is a part of South East Asia bordered by the ocean on the west east and the south, with China to the north and Cambodia and Laos to the west. The coastline stretches over $3.260 \mathrm{~km}$, with an exclusive economic zone (EEZ) of over 1 million $\mathrm{km}^{2}$ where is a habitat of a vast array of aquatic species (US Department of State, 1983; Pham, Masahide, 2007; Teh et al., 2014). Currently, with the increase in population, urbanization, industrialization, and agricultural practices, pollution with heavy metals in an aquatic ecosystem may occur (Gupta et al., 2009). Mercury (Hg) is one of the most toxic metals in the aquatic ecosystems, which originates both from natural sources and human activities (Luciana et al., 2005; Seyed et al., 2013). Hg cannot be degraded; it is deposited in the aquatic sediments and can be bioaccumulated and biomagnified via the food chain, and finally assimilated by human consumers, which results in health risks (Grimanis et al., 1978; Adams et al., 1992; Ermosele et al., 1995; Smith et al., 1996; Zweig et al., 1999; Agah et al., 2009; Malik et al., 2010).

It is well known that fish play an important role in the human diet. Fish is not only a source of proteins and healthy fats, but it is also a unique source of essential nutrients, including long-chain omega-3 fatty acids, iodine, vitamin D, and calcium (FDA, 2006; Kruzikova et al., 2013; Vicarova et al., 2015). However, it can represent a dangerous source of some heavy metals, especially Hg (Kruzikova et al., 2013).

According to Stankovic et al. (2014), microbes, fungi, plants, animals, and humans are used as bioindicators of heavy metals (including $\mathrm{Hg}$ ) originating from the air, water, sediment, soil, and the food web. Therefore, fish could be a good and effective indicator of these elements in the aquatic environment. Fish represent a specific level 
of the trophic pyramid and links Hg to the ecosystem by bioaccumulation and biomagnification (Stankovic et al., 2014; Łuczyńska et al., 2016)

In this study, two fish species were collected: Whipfin silver biddy and Flathead grey mullet. These species are abundant and an easily accessible resources for artisanal fishing communities and are popular on Vietnam fish markets. There is some published literature on $\mathrm{Hg}$ content of these two species in the world (Legorburu et al., 1988; Meng-Hsien Chen, 2002; Yilmaz, 2003; 2005; Chouba et al., 2007; Sih-Wei Huang et al., 2008; Frías-Espericueta et al., 2016; Türkmen et al., 2016; Ruelas-Inzunza et al., 2017; Delgado-Alvarez et al., 2017; Dung et al., 2018), but the data for Vietnam is scarce.

Therefore, the aim of this study was to determine the effect of fish species on $\mathrm{Hg}$ concentrations in the selected organs (muscle, liver, and gills) of Whipfin silver biddy and Flathead grey mullet. The data obtained were used to access the level of risk associated with consumption two these fish species in Vietnam. Moreover, the study also evaluates differences between the content of $\mathrm{Hg}$ in organs of the same fish.

\section{Material and methods}

During July, August, and September 2017, fish samples were obtained from local fishermen and the fish market of coastal Vietnam of Nghe An, Ha Tinh, Quang Binh, Quang Tri and Hue. Two fish species were collected as Whipfin silver biddy - Gerres filamentosus Cuv. $(\mathrm{n}=28)$ and Flathead grey mullet - Mugil cephalus $\mathrm{L} .(\mathrm{n}=48)$. The muscle tissue from the dorsal area, the liver, and gill tissue were collected, placed in labelled polypropylene bags and stored at $-20^{\circ} \mathrm{C}$ until analysis.

Total mercury concentrations in samples were determined by cold vapour atomic absorption spectrometry (NIC, MA-2; limit of quantification was $0.2 \mathrm{ng}$ per sample). Data was presented in $\mu \mathrm{g} \mathrm{g}^{-1}$ wet weight.

The one-way analysis of variance ANOVA and Duncan's test was used to test significant interspecific differences in the content of mercury both between species and the organs of the same species. Statistical significance was declared when the p value was equal to or less than 0.05 .

\section{Results and discussion}

The highest Hg concentrations in Flathead grey mullet were found in the liver, followed by muscle and gills $\left(0.195,0.097\right.$ and $0.046 \mu \mathrm{g} \mathrm{g}^{-1}$ w.w., respectively - Tab.1). 
Tab. 1. Mercury concentrations ( $\mu \mathrm{g} \mathrm{g}^{-1}$ wet weight) in gills, liver, and muscle of Flathead grey mullet (n $=48)$

\begin{tabular}{lllll}
\hline Tissue & Mean & \pm SD & Min & Max \\
\hline Gills & 0.046 & 0.016 & 0.015 & 0.075 \\
Liver & 0.195 & 0.101 & 0.063 & 0.494 \\
Muscle & 0.097 & 0.037 & 0.027 & 0.184 \\
\hline
\end{tabular}

Note: SD - standard deviation, Min - minimum, Max - maximum

There are several studies of $\mathrm{Hg}$ concentrations of Flathead grey mullet available in the literature. Mostly, the concentrations reported are lower than the mean value found in this study (Sankar et al., 2006; Dural et al., 2007; Ruelas-Inzunza et al., 2008; Sih-Wei Huang et al., 2008; Squadrone et al., 2013; Ruelas-Inzunza et al., 2017). However, there were also some reported $\mathrm{Hg}$ concentration higher than the mean we obtained (Chouba et al., 2007; Frías-Espericueta et al., 2016) (Tab. 2).

Tab. 2. Mean total $\mathrm{Hg}$ concentrations ( $\mu \mathrm{g} \mathrm{g}^{-1}$ wet weight) in Flathead grey mullet

\begin{tabular}{cccccc}
\hline \multicolumn{2}{c}{ Mean Hg concentration } & & Location & References \\
\cline { 1 - 3 } Gills & Liver & Muscle & & Central Vietnam & This study \\
\hline 0.046 & 0.195 & 0.097 & & California US State & Ruelas-Inzunza et al. (2017) \\
- & 0.050 & 0.032 & & Northwestern Mexico & Frías-Espericueta et al. (2016) \\
- & 0.503 & 0.036 & & Mediterranean sea & Squadrone et al. (2013) \\
- & - & $<0.025$ & & Northwestern Mexico & Ruelas-Inzunza et al. (2008) \\
- & - & 0.016 & & Tainan, Taiwan & Sih-Wei Huang et al. (2008) \\
- & 0.044 & 0.110 & & Mediterranean sea & Dural et al. (2007) \\
- & - & 0.025 & & Tunisian lagoon (Winter) & Chouba et al. (2007) \\
- & 0.242 & 0.098 & & Tunisian lagoon (Spring) & Chouba et al. (2007) \\
- & 0.231 & 0.084 & & Tunisian lagoon (Summer) & Chouba et al. (2007) \\
- & 0.247 & 0.102 & & Tunisian lagoon (Autumn) & Chouba et al. (2007) \\
- & - & 0.040 & & Calicut, India & Sankar et al. (2006) \\
\hline
\end{tabular}

Tab. 3. Mercury concentrations ( $\mu \mathrm{g} \mathrm{g}^{-1}$ wet weight) in gills, liver, and muscle of Whipfin silver biddy $(\mathrm{n}=28)$

\begin{tabular}{lcccc}
\hline Tissue & Mean & \pm SD & Min & Max \\
\hline Gills & 0.077 & 0.040 & 0.036 & 0.220 \\
Liver & 0.245 & 0.187 & 0.078 & 0.643 \\
Muscle & 0.460 & 0.200 & 0.233 & 1.095 \\
\hline
\end{tabular}

Note: SD - standard deviation, Min - minimum, Max - maximum

Concentrations of $\mathrm{Hg}$ in gills, liver, and the muscle of Whipfin silver biddy differed between themselves (Tab. 3). The highest mean was noted in muscles $\left(0.460 \mu \mathrm{g} \mathrm{g} \mathrm{g}^{-1}\right.$ w.w), followed by the liver and gills ( 0.245 and $0.077 \mu \mathrm{g} \mathrm{g}{ }^{-1} \mathrm{w} . \mathrm{w}$, respectively). In this study, $\mathrm{Hg}$ accumulation in muscles and the liver was higher than previously reported 
by Meng-Hsien Chen (2002), Sih-Wei Huang et al. (2008), and Dung Le Quang et al. (2018). According to Meng-Hsien Chen (2002), Hg concentrations in muscles and livers of Whipfin silver biddy were both $0.025 \mathrm{\mu g} \mathrm{g}^{-1}$ w.w..In muscles, Sih-Wei Huang (2008) recorded $0.45 \mu \mathrm{g} \mathrm{g}^{-1}$ w.w., and Dung Le Quang (2018) recorded $0.358 \mu \mathrm{g} \mathrm{g}^{-1}$ w.w.

There were significant differences in mercury contents in muscles and gills between both species in this study $(\mathrm{p}<0.05)$. However, there was no difference in the concentration of $\mathrm{Hg}$ in livers between Flathead grey mullet and Whipfin silver biddy (Tab. 4).

Tab. 4. Differences in Hg concentration ( $\mu \mathrm{g} \mathrm{g}^{-1}$ wet weight) between the organs of both species

\begin{tabular}{llccccc}
\hline Tissue & \multicolumn{1}{c}{ Species } & Mean & $\begin{array}{c}\text { Statistical } \\
\text { results }(\mathrm{p})\end{array}$ & \pm SD & Min & Max \\
\hline \multirow{2}{*}{ Gills } & Whipfin silver biddy & 0.077 & \multirow{2}{*}{0.000} & 0.040 & 0.036 & 0.220 \\
& Flathead grey mullet & 0.046 & & 0.016 & 0.015 & 0.075 \\
\multirow{2}{*}{ Liver } & Whipfin silver biddy & 0.245 & \multirow{2}{*}{0.132} & 0.200 & 0.233 & 1.095 \\
& Flathead grey mullet & 0.195 & & 0.037 & 0.027 & 0.184 \\
\multirow{2}{*}{ Muscle } & Whipfin silver biddy & 0.460 & \multirow{2}{*}{0.000} & 0.187 & 0.078 & 0.643 \\
& Flathead grey mullet & 0.097 & & 0.101 & 0.063 & 0.494 \\
\hline
\end{tabular}

Note: SD - standard deviation, Min - minimum, Max - maximum

The mean Hg concentrations determined in this study for Flathead grey mullet are one order of magnitude lower than the maximum permissible threshold $(0.5 \mu \mathrm{g} / \mathrm{g}$ w.w. $=2 \mu \mathrm{g} / \mathrm{g}$ d.w.; FAO-WHO, 2003; Ministry of Health of Vietnam, 2007), which suggests wide limits of safety for the consumption of these fish species. It is not the same in the case of Whipfin silver biddy, because the Hg concentration $\left(0.460 \mu \mathrm{g} \mathrm{g}^{-1} \mathrm{w} . \mathrm{w}\right)$ in the muscle of this species almost reached the maximum permissible level.

The result of this study agree with the views of Türkmen et al. $(2011 ; 2016)$ and Azevedo et al. (2012), which describe that, in most fish species, the liver is the main storage place for metals. However, this is not a general rule in the case of $\mathrm{Hg}$. We detected higher content of $\mathrm{Hg}$ in muscle than in liver in Whipfin silver biddy, as did Coelho et al. (2010) and Polack-Juszczak (2015). Additionally, Waltham et al. (2013) and Diop and Amara (2016) found no differences between $\mathrm{Hg}$ concentrations in livers and muscles of some fish species.

The difference in $\mathrm{Hg}$ concentration in organs of fish between the two species may be explained by several factors, such as resident time, trophic transfer, growth rate, prey type, and dietary quality. All of them can affect the Hg bioaccumulation in fish communities (Hall et al., 1997; Marugo-Negrete et al., 2008). Among others factors, feeding habits have been recognised as a prime reason for $\mathrm{Hg}$ contamination (Hall et al., 1997). 
Statistically significant differences in mean Hg levels were observed between two fish species investigated (Whipfin silver biddy - Gerres filamentosus Cuv. and Flathead grey mullet - Mugil cephalus L.) and their tissues, (except for their livers, there is no statistical difference between the two observed species). These results supply information on $\mathrm{Hg}$ contents in tissues of the species examined in coast central Vietnam and indirectly indicate $\mathrm{Hg}$ levels in the marine environment. These results can be used to understand the chemical quality of fish and to evaluate the possible risk associated with their consumption.

References

Adams, W.J., Kimerle, R.A., Barnett, J.W. (1992). Sediment quality and aquatic life assessment. Environmental Science and Technology, 26, 1865-1875.

Agah, H., Leermakers, M., Elskens, M., Fatemi, S.M.R., Baeyens, W. (2009). Accumulation of trace metals in the muscles and liver tissues of fve fish species from the Persian Gulf. Environmental Monitoring Assessment, 157, 499-514. DOI: 10.1007/s10661-008-0551-8.

Azevedo, J.S., de Souza-Sarkis, J.E., Oliveira, T.A., Ulrich, T. (2012). Tissue-specific mercury concentrations in two catfish species from the Brazilian coast. Brazilian Journal of Oceanography, 60, 211-219. DOI: $10.1590 /$ S1679-87592012000200011

Chouba, L., Kraiem, M., Njimi, W., Tissaoui, C.H., Thompson, J.R., Flower, R.J. (2007). Seasonal variation of heavy metals ( $\mathrm{Cd}, \mathrm{Pb}$ and $\mathrm{Hg}$ ) in sediments and in mullet, Mugil cephalus (Mugilidae), from the Ghar El Melh Lagoon (Tunisia). Transitional Waters Bulletin, 4, 45-52. DOI: 10.1285/i1825229Xv1n4p45

Coelho, J.P., Santos, H., Reis, A.T., Falcão, J., Rodrigues, E.T., Pereira, M.E., Duarte, A.C., Pardal, M.A. (2010). Mercury bioaccumulation in the spotted dogfish (Scyliorhinus canicula) from the Atlantic Ocean. Marine Pollution Bulletin, 60, 1372-1375. DOI: 10.1016/j.marpolbul.2010.05.008

Delgado-Alvarez, C.G., Frías-Espericueta, M.G., Ruelas-Inzunza, J., Becerra-Álvarez, M.J., Osuna-Martínez, C.C., Aguilar-Juárez, M., Osuna-López, J.I., Escobar-Sánchez, O., Voltolina, D. (2017). Total mercury in muscles and liver of Mugil spp. from three coastal lagoons of NW Mexico: concentrations and risk assessment. Environmental Monitoring and Assessment, 189, 312. DOI: 10.1007/ s10661-017-6020-5

Diop, M., Amara, R. (2016). Mercury concentrations in the coastal marine food web along the Senegalese coast. Environmental Science and Pollution Research, 23, 11975-11984. DOI: 10.1007/s11356-0166386-x

Dung Le, Q., Satyanarayana, B., Siau, Y., F., Kotaro, S. (2018). Mercury bioaccumulation in tropical mangrove wetland fishes: Evaluating potential risk to coastal wildlife. Biological Trace Element Research, 1-8. DOI: $10.1007 / s 12011-018-1313-2$

Dural, M., Goksu, M., Ozak, A. (2007). Investigation of heavy metal levels in economically important fish species captured from the Tuzla lagoon. Food Chemistry, 2, 415-421. DOI: 10.1016/j.foodchem.2006.03.001

Ermosele, C.O., Ermosele, I.C., Murktar, S.A., Birdling, S.A. (1995). Metals in fish from the upper Benue River and lakes Geryo and Njuwa in northern Nigeria. Bull. Environmental Contamination and Toxicology, 54, 8-14. 
FAO-WHO (2003). Summary and conclusions of the sixty-first meeting of the Joint FAO/WHO Expert Committee on Food Additives (JECFA), Annex 4. JECFA/61/SC. http://ftp.fao.org/es/esn/jecfa/jecfa61sc.pdf.

FDA (2006). Mercury levels in commercial fish and shellfish. Washington DC. www.cfsan.fda.gov/ frf/ sea-mehg.html.

Frías-Espericueta, M.G., Vargas-Jiménez, A., Ruelas-Inzunza, J., Osuna-López, J.I., Aguilar-Juárez, M., Bautista-Covarrubias, J.C. (2016). Total mercury in mugil spp and Eugerres axillaris of a subtropical lagoon of NW Mexico. Bulletin of Environmental Contamination and Toxicology, 97(2), 211-215. DOI: $10.1007 / \mathrm{s} 00128-016-1811-\mathrm{x}$

Grimanis, A.P., Zafiropoulos, D., Vassilaki, R., Grimanis, M. (1978). Trace elements in the flesh and liver of two fish species from polluted and unpolluted areas in the Aegean Sea. Environmetnal Science and Technology, 12, 723-726. DOI: 10.1021/es60142a001

Gupta, A., Rai, D.K., Pandey, R.S., Sharma, B. (2009). Analysis of some heavy metals in the river in water, sediments and fish from river Ganges at Allahabad. Environmental Monitoring Assessment, 157, 449-458. DOI: 10.1007/s10661-008-0547-4

Hall, B.D., Bodaly, R.A., Fudge, R.J.P., Rudd, J.W.M., Rosenberg, D.M. (1997). Food as the dominant pathway of methylmercury uptake by fish. Water, Air, Soil Polluttion, 100, 13-24.

Kruzikova, K., Kensova, R., Sedlasckova, E., Jarkovsky, J., Poleszczuk, G., Svobodová, Z. (2013). The correlation between fish mercury liver/muscle ratio and high and low levels of mercury contamination in Czech localities. International Journal of Electrochemistry Science, 8, 45-56.

Legorburu, I., Canton, L., Millan, E., Casado, A. (1988). Trace metal levels in fish from Unda river (Spain) Anguillidae, Mugillidae and Salmonidae. Environmental Technology Letters, 41, 1373-1378. DOI: 10.1080/09593338809384703

Farias, L.A., Azevedo, J., Fávaro, D.,I., Braga, E.S. (2005). Evaluation of mercury, selenium and methylmercury in fish consumed by Santos Bay communities, São Paulo, Brazil. International Nuclear Atlantic Conference - INAC, 36, 9.

Łuczyńska, J., Łuczyński, M.J., Paszczyk, B. (2016). Assessment of mercury in muscles, liver and gills of marine and freshwater fish. Journal of Elements, 21(1), 113-129. DOI: 10.5601/jelem.2015.20.2.879

Malik, N., Biswas, A.K., Qureshi, T.A., Borana, K., Virha, R. (2010). Bioaccumulation of heavy metals in fish tissues of a freshwater lake of Bhopal. Environmental Monitoring Assessment, 160, 267-276. DOI: 10.1007/s10661-008-0693-8

Marrugo-Negrete, J., Verbel, J.O., Ceballos, E.L., Benitez, L.N. (2008). Total mercury and methylmercury concentrations in fish from the Mojana region of Colombia. Environmental Geochemistry and Health, 30(1), 21-30. DOI: 10.1007/s10653-007-9104-2

Meng-Hsien, Ch. (2002). Baseline metal concentrations in sediments and fish, and the determination of bioindicators in the subtropical Chi-ku Lagoon, S.W. Taiwan. Marine Pollution Bulletin, 44, 703-714. DOI: $10.1016 /$ S0025-326X(02)00066-8

Ministry of Health of Vietnam (2007). Prescribed maximum limit of chemical and biological contamination in food, Decision 46/2007/QD-BYT 19/12, p 26.

Pham, T.T.H., Masahide, F. (2007). Impact of sea level rise on coastal zone of Vietnam. Bulletin of the Facaculty of Science, University of Ryukus, 84, 45-59.

Polack-Juszczak, L. (2015). Selenium and mercury molar ratios in commercial fish from the Baltic Sea: additional risk assessment criterion formercury exposure. Food Control, 50, 881-888. DOI: 10.1016/j. foodcont.2014.10.046

Ruelas-Inzunza, J., Meza-López, G., Páez-Osuna, F. (2008). Mercury in fish that are of dietary importance from the coasts of Sinaloa (SE gulf of California). Journal of Food Composition and Analysis, 21, 211-218. DOI: 10.1016/j.jfca.2007.11.004 
Ruelas-Inzunza, J., Kohen-Sandoval, C.K., Ramos-Osuna, M.A., Sánchez-Osuna, K.G., Spanopoulos-Zarco, P., Delgado-Alvarez, C.G., Amezcua-Martínez, F. (2017). Total mercury concentrations in white and striped Mullet (Mugil curema and M. cephalus) from a coastal lagoon in the SE Gulf of California. Journal of Environmental Science and Health, Part A., 52(5), 459-465. DOI: $10.1080 / 10934529.2016 .1271670$

Sankar, T.V., Zynudheen, A.A., Anandan, R., Viswanathan, P.G. (2006). Distribution of organochlorine pesticides and heavy metal residues in fish and shellfish from Calicut region, Kerala, India. Chemosphere, 65, 583-590. DOI: 10.1016/j.chemosphere.2006.02.038

Seyed, M.H., Noorollah, M., Nasrollah, M.S., Seyed, V.H., Amir, F.G. (2013). Risk assessment of the total mercury in Golden gray mullet (Liza aurata) from Caspian Sea. International Journal of Aquatic Biology, 1(6), 258-265.

Sih-W., Huang, Chen, Ch.-Y., Chen, M.-H. (2008). Total and organic Hg in fish from the reservoir of a chlor-alkali plant in Tainan, Taiwan. Journal of Food and Drug Analysis, 16(2), 75-80.

Smith, C.J., Hotmans, O., Cook, F.N. (1996). Accumulation of Cr, Pb, Cu, Ni, Zn and Cd in soil following irrigation with treated effluent in Australia. Journal of Environmental Pollutution, 94, 317-323. DOI: 10.1016/S0269-7491(96)00089-9

Squadrone, S., Prearo, M., Brizio, P., Gavinelli, S., Pellegrino, M., Scanzio, S. (2013). Heavy metals distribution in muscle, liver, kidney and gill of European catfish (Silurus glanis) from Italian rivers. Chemosphere, 90, 358-365. DOI: 10.1016/j.chemosphere.2012.07.028

Stankovic, S., Kalaba, P., Stankovic, A.R. (2014). Biota as toxic metal indicators. Environmental Chemical Letters, 12, 63-84. DOI: 10.10007/s10311-013-0430-6

The, L., Zeller, D., Zylich, K., Nguyen, G., Harper, S. (2014). Reconstructing Vietnam's marine fisheries catch, 1950-2010. Fisheries Centre, University of British Columbia, 2014-2017, 11p.

Türkmen, A., Tepe, Y., Türkmen, M. (2016). Determination of metals in tissues of fish species from Hurmaboğazı lagoon. Indian Journal of geo-Marine Sciences, 45, 277-282.

Türkmen, M., Türkmen, A., Tepe, Y. (2011). Comparison of metals in tissues of fish from Paradeniz Lagoon in the coastal area of northern East Mediterranean. Bulletin of Environmental Contamination and Toxicology, 87, 381-385. DOI: 10.1007/s00128-011-0381-1

US Department of State (1983). Limits in the Seas. Straight baselines: Vietnam, 99, 5-6.

Vicarova, P., Pelcova, P., Kleckerova, A., Mares, J., Kopp, R., Postulkova, E., Docekalova, H. (2015). Distribution of mercury in tissues of the Common Carp (Cyprynus carpio L.). MendelNet, 500-505.

Waltham, N.J., Teasdale, P.R., Connolly, R.M. (2013). Use of flathead mullet (Mugil cephalus) in coastal biomonitor studies: review and recommendations for future studies. Marine Pollution Bulletin, 69, 195-205. DOI: 10.1016/j.marpolbul.2013.01.012

Yilmaz, A.B. (2003). Levels of heavy metals (Fe, $\mathrm{Cu}, \mathrm{Ni}, \mathrm{Cr}, \mathrm{Pb}$ and $\mathrm{Zn}$ ) in tissue of Mugil cephalus and Trachurus mediteraneus from Iskenderun bay, Turkey. Environmental Research, 92, 277-281. DOI: $10.1016 /$ S0013-9351(02)00082-8

Yilmaz, A.B. (2005). Comparison of heavy metal levels of Grey Mullet (Mugil cephalus L.) and sea bream (Sparus aurata L.) caught in Iskendrun Bay (Turkey). Turkish Journal of Veterinary and Animal Sciences, 29, 257-262.

Zweig, R.D., Morton, J.D., Stewart, M.M. (1999). Source water quality for aquaculture: A guide for assessment. Washington DC: The World Bank, 23-24.

Abstract

The concentration of mercury (Hg) in fish species has direct consequences on the health of humans and the ecosystem. Thus, in this paper, the accumulation of $\mathrm{Hg}$ in gills, livers, and muscles of two fish species (Whip- 
fin silver biddy - Gerres filamentosus and Flathead grey mullet - Mugil cephalus) were measured by cold vapour atomic absorption spectrometry. The fish specimens were collected from local markets and direct fishing with the help of fishermen over the period from July to September 2017 in coastal Vietnam. Differences in the total $\mathrm{Hg}$ were found both between two species and organs. The concentration of $\mathrm{Hg}$ in all organs investigated of Whipfin silver biddy was higher than of Flathead grey mullet $(\mathrm{p}<0.05)$. The content of $\mathrm{Hg}$ in the muscles of Whipfin silver biddy was higher than in the livers and gills ( $\mathrm{p}<0.05), 0.460,0.245,0.077 \mu \mathrm{g}$ $\mathrm{g}^{-1}$ w.w., respectively. Livers of Flathead grey mullet had more Hg accumulated than did the muscles and gills $\left(0.195,0.097,0.046 \mu \mathrm{g} \mathrm{g}^{-1}\right.$ w.w., respectively). The results revealed that $\mathrm{Hg}$ concentrations in Flathead grey mullet did not exceed food fish safety limits established for human consumption, while the concentration of this toxic element in the muscles of Whipin silver biddy almost reached the maximum permissible level.

Keywords: Coastal Vietnam, Gerres filamentosus, Mugil cephalus, mercury

Received: [2018.05.28]

Accepted: [2018.11.20]

Stężenia rtęci w organach pobranych od Gerres filamentosus (Cuv.) i Mugil cephalus (L.) z Wietnamu

Streszczenie

Akumulacja rtęci (Hg) w rybach ma (duże, choć pośrednie) bezpośrednie znaczenie dla zdrowia ludzi i ekosystemu. Dlatego w tym projekcie zbadano stężenia $\mathrm{Hg}$ w skrzelach, wątrobie i mięśniach dwóch gatunków ryb (Gerres filamentosus i Mugil cephalus). Badania przeprowadzono z wykorzystaniem techniki atomowej spektrometrii absorpcyjnej z przystawką zimnych par. Osobniki ryb zostały (kupione) pozyskane na lokalnych targach lub bezpośrednio od rybaków w okresie między lipcem a wrześniem 2017 r. w Wietnamie. Różnice w stężeniach rtęci były obserwowane zarówno między badanymi gatunkami, jak i tkankami (materiałami). Stężenia Hg wykryte we wszystkich materiałach pobranych od Gerres filamentosus były wyższe niż w materiałach pobranych od Mugil cephalus ( $\mathrm{p}<0,05)$. Stężenia Hg w mięśniach Gerres filamentosus były wyższe niż w wątrobie i skrzelach (p < 0,05), odpowiednio 0,460, 0,245 i 0,077 $\mu \mathrm{g} \mathrm{g}{ }^{-1} \mathrm{~m} . \mathrm{m}$. (mokrej masy). Wątroba Mugil cephalus zakumulowała wyższe stężenia Hg niż mięśnie i skrzela (odpowiednio 0,195; 0,097 i $0,046 \mu \mathrm{g} \mathrm{g}{ }^{-1} \mathrm{~m} . \mathrm{m}$. Wyniki wskazują, że stężenia rtęci u Mugil cephalus (badanych gatunków) nie przekraczają norm ustalonych dla żywności do spożycia przez ludzi. Jednak poziom Hg w mięśniach Gerras filamentosus jest zbliżony do tej wartości, co stanowi pewne zagrożenie dla potencjalnych konsunentów.

Słowa kluczowe: Wietnam, Gerres filamentosus, Mugil cephalus, rtęć

Information on the authors

\section{Thiep Vo Van}

He is mostly interested in fish biology and fish toxicology.

Łukasz J. Binkowski https://orcid.org/0000-0001-7271-2371

$\mathrm{He}$ is specialised in the ecotoxicology and biomonitoring of metals in the environment and animals.

Robert Stawarz https://orcid.org/0000-0002-0495-1730

His main scientific interests are dedicated to toxicology and physiology. 